\title{
Assessment of the Stability in the Foundation of Structures in Permeable Soils
}

\author{
Keshtkar SINA ${ }^{1}$ \\ ${ }^{1}$ Master of Civil Engineering - Sina.keshtkar@live.com
}

\begin{abstract}
Problem of seepage in the foundation of canal structures is one of the most important issues in civil engineering in water Tendency. There exist several failures in different canal sections constructed in Guilan drainage system due to penetration of ground flow through permeable media of the soil. In this study, following series of chemical, physical and strength tests, the effect of leaching has been appointed and investigated on the north Iran's clay soils. This study indicates that as a result of leaching the soil structure have become porous and removal the soluble salts and part of the fine particle change the dry unit weight, void ratio, specific gravity and hydraulic conductivity. Also, leaching cause the reduction of mechanical properties and unconfined compressive strength, Elasticity of modulus, Cohesion and friction angle in two conditions as drained and un-drained conditions. Finally, using the result of laboratory tests and comparison with the results of a case study using a numerical approach, the effect of leaching in sliding has been investigated.
\end{abstract}

Keywords: Stability, Soil, Foundation, Structure, Modulus of Elasticity

\section{Introduction}

Problem of soil stabilization in permeable media has been an argued issue in the recent years. Effect of salts in soils to pay attention to from long time ago. Salts influence specially on physical and geotechnical behavior of soils $[1,2]$. This may cause marked changes in the forces between colloidal particles [3]. In other words leaching means reduce or removal salts that this process cause reduce Electrical conductivity (EC) of saturate soil soluble $[4,5]$. Preconsolidation pressure in the unconfined lab specimens. The tri-axial tests results show a decrease in the effective stress strength parameters due to leaching. Field leaching has resulted in reduction in the dynamic cone penetration resistance [5]. Study of Guarnieri and Molari (2000) on two different Italian soils show that the soil sensitive to the saline action 
greatly increased liquid limit and shear resistance [2]. Sridharan and Gajarajan (1987) show that influence of fluoride on montmorillonites and aluminum extracted from the clay lattice resulted in reduction liquid limit, $G_{s}$ and increase void ratio for bentonit clay and montmorillonit clay [6]. Lebron and atc (1994) evaluation the calcareous saline-sodic soils and indicate that liquid limit decreased an average of $25 \%$ when the EC decreased from 40 to $2(\mathrm{ds} / \mathrm{m})[7]$.

Anson and Hawkins (1998) carry out leaching with $\mathrm{Cacl}_{2}$ solution on the sodium kaolinit and montmorillonit that showed increasing ion $\mathrm{Ca}^{2+}$ concentration and replacing with $\mathrm{Na}{ }^{+}$ recovery the liquid limit. Also resulted in reduction residual shear strength. Maybe this resulted to some condition of direct shear test wasn't controllable [8]. The effect of leaching on the properties of cemented sand deposits in Kuwait was examined by Ismael and Molla (1998) on samples taken from two sites with different cementation levels. The results indicate increased compressibility and a reduction of $C^{\prime}$ and $\phi^{\prime}$ due to leaching [9]. Effect of leaching was examined in Strait of Canso's sediments in Canada indicate reduction strength, A parameter of Skempton and Elasticity of modulus [10]. A comparative study has been made on Indian fly ash by Yudbhir and Kumar Das (2006) that show reduction of ion $\mathrm{Ca}^{2+}$ resulted in reduction unconfined compressive strength and modulus of elasticity [11]. A steel structure factory that was placed an eastern Saudi Arabian virgin deposits was considered. It was found that the increase in the moisture content and removal salts could reduce the SPT $(\mathrm{N})$ values [12].

\section{Laboratory test}

The soil that has been considered this study is North of Iran clay. Three type of test carry out in this study that such as: chemical, physical and strength test. Making the samples for these tests according that with having the information of compaction test on these samples using the cylinder in $9 \mathrm{~cm}$ length and $3.75 \mathrm{~cm}$ diameter and tamper $800 \mathrm{gr}$ in weight. These samples have been compacted in optimum water content and void ratio. Then unconfined test carry out on the samples with various salts one time in wet optimum face and another in dry optimum face. So samples was making in molds with $4.9 * 4.9 * 1.9 \mathrm{~cm}$ dimension.

\section{Results}


For the considered soil content of EC was calculated $17.94(\mathrm{mmho} / \mathrm{cm})$. Then this soil was stand on leaching phenomenon in special container. This phenomenon cause to removal of salts and reduction EC in soil. The soil on the leaching process divided in to 8 samples ( $\mathrm{A}, \mathrm{B}, \mathrm{C}, \mathrm{D}, \mathrm{E}, \mathrm{F}, \mathrm{G}, \mathrm{H})$ that sample $\mathrm{A}$ is the natural of soil and sample $\mathrm{H}$ is the after leaching condition. These 8 samples have various EC. Also result of the direct shear test was shown in table1:

Table 1: Result of direct shear test on the samples

\begin{tabular}{ccccc}
\hline$\phi_{C U}(\mathrm{deg})$ & $\phi_{C D}(\mathrm{deg})$ & $C_{C D}\left(\mathrm{Kg} / \mathrm{cm}^{2}\right)$ & $C_{C U}\left(\mathrm{Kg} / \mathrm{cm}^{2}\right)$ & samples \\
\hline \hline 9.12 & 23.5 & 0.11 & 0.37 & $\mathrm{~A}$ \\
\hline 6.54 & 20 & 0.07 & 0.31 & $\mathrm{~B}$ \\
\hline 6.11 & 17 & 0.057 & 0.28 & $\mathrm{C}$ \\
\hline 5.48 & 16.5 & 0.05 & 0.26 & $\mathrm{D}$ \\
\hline 4.62 & 14.5 & 0.041 & 0.22 & $\mathrm{E}$ \\
\hline 4.58 & 14.2 & 0.037 & 0.191 & $\mathrm{~F}$ \\
\hline 4.53 & 13.8 & 0.034 & 0.18 & $\mathrm{G}$ \\
\hline 4.5 & 13.3 & 0.03 & 0.17 & $\mathrm{H}$ \\
\hline
\end{tabular}

\section{Discussion}

Just as shown from table1 effect of leaching and diminished EC in rate of 95.5 percent cause to reduction liquid (LL) limit in rate of 27.8 percent. Ismael (1993) study on the Arabian coastal saline soils that were placed unified classification ML and there were salts such as gypsum and anti-dry on there structures changing the LL had been calculated reduction in rate of 34 percent. In this study leaching cause to reduction EC in rate of 93 percent [5]. Different with this study can express at different in type of soil and type of salts. Studies of Guarnieri \& Molari (2000) on two type of clay in Italy had been expressed reduction LL in result of leaching. That this reason can express in different in type of mineralogy. Also another different between in two studies can expressed reversion at effect of salts way. As so as salts had been edited Saline water [2].

Also studies of Sridharan \& Gajarajan (1987), Lebron report et al (1994) and Hawkins \& Anson (1998) had been accepted this results. Existence difference between in two studies was reversion of way of addition salts namely addition of calcium ions. Ismael study (1993) on the 
coastal saline soils in Persian Gulf indicated that decrease LL and PL in result of leaching process and reduction EC in rate of 93 percent [5]. That can express different in type of soils and type of salts are different between in this two study but absolutely in this study too removal of salts that increase the plasticity of soils cause to reduction PL [5]. Also studies of Molari \& Guarnieri (2000) on the two Italian clay soils express the increasing PL in result of reduction salts [2]. Hawkins\& Anson studies (1998) had been accepted this result too [8]. Changing of plastic limit (PL) depended on to type of mineralogy; also path of this study is reversion of present study that means salts had been added to soils. In present study be indistinct the type mineralogy and type of salts but similarity between two study reduction in total of salts and similar conclusion.

Also table 1 indicated that reduce plasticity index (PI) in rate of 30.7 percent in leaching process and reducing EC. That this phenomenon could be reduction the salts of that export plasticity property to soils. May exist salts that with add to soil be increased the strength of soils. Such as Puppala (2004) study that against of present study was added Portland cement in soils accompanies was improving strength property resulted to decreasing PI.

Portland cements with be addition to soils decreasing the plasticity property that in this study in result of different in type of method, type of salts and type of soils (was sand) was apposite result with present study [18]. Study of Ismael (1993) on the coastal saline soils in Persian Gulf (ML) denounce that decreasing plasticity index (PI) and had been no plastic in result of leaching process and decreasing EC in rate of 93 percent [5], whereas existence gypsum salts in this soil cause to improving plasticity property. Reduction plasticity index in leaching process had been resulted. Exaction of this result and probability existence of gypsum salts had been in present study.

Results had been indicated that in result of leaching and reducing EC in rate of 95.5 percent, reduction slowly in $G_{s}$, increasing e and finally reduction in $\gamma_{d}$ had been happened in soil samples. In present study reduction $\gamma_{d}$ in rate of 13 percent and increasing void ratio in rate of 26 percent was happened. This phenomenon could be explained that solving the crystals of salts in result of cementing and exiting part of fine particle from soil structure. That really tendency of soil had been to finer particle and reduction $G_{s}$, and in result of removal salts and destroying the cementing link porosity of soils had been increased, also another reason on the increasing void ratio maybe replacing Ions that had large hydration radius with Ions that had little hydration radius that cause to reduction in diffuse double layer and increasing void ratio. 
Ismael (1993) study on coastal saline soils in Persian Gulf denounce that relative reduction $G_{s}$ in leaching process and reduction EC in rate of 93 percent [5]. Different between this study and present study had existing, be different leaching container that had special effect on the leaching manner. Ismael (1998) study on the cementing sands in Kuwait indicated that $G_{s}$ had not been changed in leaching process [11].

Also Sridharan \& et al (1987) study on bentonite clay reduction in $G_{s}$ had been resulted too. Studies of Ismael (1993) on coastal saline soils in Persian Gulf indicated that leaching cause to reduction $\gamma_{d \max }$ in rate of 3.84 percent and increasing e in rate of 7.31 percent [5]. Study of Ismael (1998) on cemented sandy soils in Kuwait indicated that leaching process cause to increasing void ratio of Kiefn region in rate of 3 percent [11]. Also Moore \& et al (1977) with laboratory study of leaching on the Strait of Canso's sediments in Canada indicated that leaching with $\mathrm{NaOH}$ increase the void ratio of soil that accept these results.

Finally results of table 1 denounce on increasing Hydraulic conductivity (K) in rate 97 percent in leaching process. This reason as so as had been explained later was increasing the soil void ratio in leaching process that cause to increasing K.studies of Hasan-Alsanad \& Basel ALBader (1990) on the calcareous soils in Kuwait denounce on increasing K in result of leaching process [1]. Ismael (1993) had been calculated similar results that similarity of this study with present study using distilled water in leaching process.

But had different in type soils, type of salts, concentration of salts and type of method whereas in Ismael study against that present study samples had been to experimented undisturbed. Molari \& Guarneri (2000) studies on two clays in Italy had showed that K had been decreased in result of increasing salts and sodium absorbed percent in soils [2]. Abduljauwad \& Al-Amoudi (1995) with study leaching process on the saline soils in Persian Gulf with distilled and brackish water discovered that leaching with distilled water cause to increasing $\mathrm{K}$ in rate of orderly 120 and 9 percent in constant head and falling head tests. Incidentally leaching did not have any Effect on $\mathrm{K}$ that all these studies accepted the results of present study [19].

Also Abduljauwad et al (1994) studies on the silt saline soils in Persian Gulf reduction in $q_{u}$ in result of reduction salts had been resulted. Yudbhir \& Kumar Das (2006) had been studied on the India sands had been discovered reduction $q_{u} \& E_{S}$ in result of reduction calcium Ions that accepted these results [11]. This reason was explained similar to unconfined compressive strength test to be loose and porous structure in soils and reduction density of soils due to leaching process. Guarnieri \& Molari (2000) studies on two clays in Italy denounce on 
increasing strength parameters from direct shear test due to increasing Electrical conductivity (EC) [2].

In this study backfill overhanging on the right Sangar's canal in the Rasht city in north of Iran have been selected as a case study. In this study results of changing the mechanical parameters of soils in result of leaching assign to the models of case study and analysis of slope stability have been investigated.

The software that was using in analysis of slope is SLOPE/W that is underneath of GEOSLOPE. Efficiency of this software is base the limit equilibrium method (L.E.M). That can calculate the critical slope surface and minimum safety factor against the sliding. In this study analysis of slope was carried out only from Janbu, ordinary and bishop method and so. Was calculated from SEEP/W than another underneath of GEO-SLOPE and assign to considered model.

Base of SEEP/W's act is finite element method [17].

\section{Discussion}

The results obtained from this study show that:

Peneteration of the water flow into the soil surrounding the canal structure can have a significant effect on soil behavior.

Increasing the void ratio in resulted of leaching cause to formation porous and compressible structure in soils.

In result of leaching and formation the porous structure in soils unconfined compressive strength and modulus of elasticity decreased.

In result of leaching cohesion and friction angle in drained and un-drained condition decreased.

Reduction shear strength of soils in result of leaching cause to reduction safety factor of slopes in sliding.

Changing of direct shear test results respect to unconfined compressive test result affected by leaching cause to greater reduction in safety factor in sliding.

\section{References}

1-Al-Sanad, hasan., B. Al-Bader, 1990, Laboratory study on leaching of calcareous soil from

Kuwait, J. Geotech. Eng, Vol.116, No.12, pp.1797-1809.

2-Guarnieri, A., A. Fabbri., G. Molari, 2005, Influence of sodicity and salinity on the 
mechanical properties of two Italian soils, Silsoe Research Institute, pp239-243.

3-Mitchell, James. K, 1992, Foundamentals of soil behaviour, University of California, Berkeley, Second Edition.

4-Al-Amoudi, O. S. B., S. N. Abduljauwad, 1994, Shear strength characteristics of Sabkha soils, J. Geotech. Engrg, Vol.120, No.11, pp. 654-663.

5-Ismael, Nabil. F, 1993, Laboratory and field leaching tests on coastal salt-bearing soils, J.Geotech. Engrg, Vol.119, No.3, pp.453-470.

6-Sridharan, A., S. M. Rao., V. S. Gajarajan, 1987, Influence of fluride on the compressibility of montmorillonites, Geotechnique 37, No.2, 197-206.

7-Lebron, I., D. L. Suarez., F. Alberto, 1994, Stability of a calcareous saline-sodic soil during reclamation, Soil Sci. Soc. Am. J. 58: 1753-1762.

8-Anson, R. W. W., A. B. Hawkins, 1998, The effect of calcium ions in pore water on the residual shear strength of kaolinite and sodium montmorillonite, Geotechnique 48, No. 6 , 787-800.

9-Ismael, Nabil. F., M. A. Mollah, 1998, leaching effects on properties of cemented sands in Kuwait, J. Geotech. Eng, Vol.124, No.10, pp.997-1004.

10-Moore, J. G., J. D. Brown., M. A. Rashid, 1977, The effect of leaching on engineering behaviour of a marine sediment, Geotechnique 27, No.4, 517-531.

11-Sarat, Kumar. Das., Yudhbir, 2006, Geotechnical properties of low calcium and high calcium fly ash, Geotechnical and Geological Engineering, 24: 249-263.

12-Sabtan, Abdullah. A, 2005, Performance of a steel structure on Ar-Rayyas Sabkha soils, Geotechnical and Geological Engineering, 23: 157-174.

13-Jahanandish, mojtaba and et al., 2004, Investigation of tridimentional methods stability of backfill slopes, 7th civil engineering international congress.

14-Cheng, Y. M, et al, 2007, Two-dimensional slope stability analysis by limit equilibrium and strength reduction methods, Computers and Geotechnics 34, pp137-150.

15-Asgary, Farajollah., Farzaneh, Orang, 2002, tridimentional analyses stability of slopes in L.E.M method, Engineering faculty of Tehran university puplication, Wrapper36, Number3, PP.371-381.

16-Paye, A. L., R. H-Miller and D. R. Keeny. Methods\&soil Analysis, Part I., SSSA Inc. Madison,WI.1984.

17-Geostudi 2004 (Ver.6.02), SLOPE/W Users Manual, 2004, Edited by john Krahn, GEOSLOPE/W International ltd, Web: http://www.geo-slope.com. 
18-Puppala, Anand. J., J. A. Griffin, L. R. Hoyos, S. Chomtid, 2004, Studies on sulfateresistant cement stabilization methods to address sulfate-induced soil heave, Journal of Geotechnical\&Geoenvironmental engineering, Vol.130, pp.391-401.

19- Abduljauwad, S. N., O. S. B. Al-Amoudi, 1995, Geotechnical behaviour of saline sabkha soils, Geotechnique 45, No. 3, 425-445. 